\title{
OPTIMIZATION OF PCR PURIFICATION USING SILICA-COATED MAGNETIC BEADS
}

\author{
Berdimuratova K.T., Amirgazin A.O. Kuibagarov M.A., Lutsay V.B., \\ Mukanov K.K., Shevtsov A.B. \\ National Center for Biotechnology \\ 13/5, Korgalzhyn road, Nur-Sultan, 010000, Kazakhstan \\ bianco-umka@mail.ru
}

\begin{abstract}
Purification of nucleic acids is still an important step in molecular genetic research. The development of whole genome sequencing technologies has increased the requirements for the purity of the nucleic acids used, and also required the selection of DNA fragments by size. Buffer systems that contain PEG/NaCl solutions and silica-coated magnetic beads allow to purify nucleic acids and selectively sorb certain sizes of DNA. In this article, we present a simple protocol for the purification of PCR products with the ability to absorb the required DNA molecules. It was determined that the use of an optimized PEG / NaCl buffer system with magnetic silica gel in a ratio of 1.5: 1 with a PCR product allows to get rid of DNA fragments 100 and less base pairs (bp), as well as other contaminants, while maintaining this is more than $90 \%$ of the DNA in solution. The ratio of 0.35 : 1 allows for high-affinity sorption of DNA molecules larger than $400 \mathrm{bp}$. The practical use of the obtained data allows us to improve the quality of sequencing without increasing the cost of research.
\end{abstract}

Key words: silica-coated magnetic beads, purification, DNA, PCR products.

\section{INTRODUCTION}

Nucleic acid purification methods that are used in genetic analysis and identification of biological objects play a crucial role in research in the field of life sciences. [1]. For diagnostic and research purposes, it is necessary to isolate nucleic acids from various objects including bacteria, virus-containing liquid, tissues and exudates of higher organisms. To isolate nucleic acids, there is a huge selection of commercially available kits and open protocols that make it possible to obtain highly purified nucleic acids from impurities of cell walls, proteins and chemical compounds $[2,3]$.

Another important task of molecular biology is to purify PCR products for subsequent cloning or sequencing including preparing libraries for sequencing on high performance sequencers. [4]. Two main factors affect the quality of the resulting sequences: the concentration, integrity, and purity of the DNA matrix; effective removal of primer residues, unbound deoxynucleotide triphosphates, proteins and chemical compounds [5]. In addition, to clear libraries for whole genome sequencing, it is necessary to select PCR products by size, removing non-specific low-molecular and high-molecular DNA fragments formed during the demirization of primers and DNA fragmentation. Methods for cleaning PCR products can often be expensive, timeconsuming, and can lead to partial or complete loss of the original DNA template. The determination of a nucleic acid purification technique may depend on several factors, 
such as cost, operating time, the need for high-performance processing, the quality of sequence data, and user preferences. Numerous approaches are available for purification of PCR products, including alcohol precipitation [6], affinity chromatography [7], size exclusion chromatography methods [8-10], proprietary kits, and the use of paramagnetic particles or beads [11-12]. Among these methods, the method of cleaning nucleic acids with paramagnetic particles coated with silica gel has a number of advantages. The use of magnetic silica gel reduces operating time and costs and increases the integrity of the DNA. [13]. Also, magnetic extraction does not use harmful organic solvents, the protocols are simple and allow you to automate the processes. [14]. Magnetic silica gel has been widely used in cleaning up "libraries" for whole genomesequencing, as it has several advantages: unlike cleaning libraries on spin column, it does not require a centrifugation stage, which allows you to automate and scale the cleaning process [15]; get rid of low molecular weight DNA fragments [16]; get rid of long DNA molecules [17].

Magnetic silica gel has a ferrite core coated with silica or carboxylic polymer, which eliminates the oxidation of iron and prevents the loss of its properties, and also facilitates the sorption of nucleic acids. These properties of magnetic silica gel allow reversible binding of nucleic acid under conditions of dehydration and in the presence of a strong magnet can be safely immobilized during several stages of washing and manipulation [18]. The particle structure and composition of the solution can be modified to selectively adsorb nucleic acids depending on their type and size. These properties were used to develop purification methods based on a three-stage process of binding, washing and elution. In an optimized binding solution, the particles selectively adsorb nucleic acids from complex mixtures. An external magnetic field is used to remove particles and adherent target nucleic acid from unbound material. Flushing particles eliminates residual contamination. The purified target nucleic acid is then eluted, ready for subsequent applications. This technology was developed as an alternative to vacuum filtration and centrifuge-based cleaning formats to ensure high sample processing performance. Commercially available kits are expensive and significantly increase the cost of the sequencing process. In this regard, many groups develop their protocols using ready-made or self-prepared silica gels [19]. However, it is necessary to optimize the conditions for cleaning nucleic acids for a certain type of magnetic silica gel.

In this article we present an optimized method of nucleic acid purification that demonstrates quality results comparable to data obtained using more expensive commercial kit.

\section{Materials and methods}

In this work was used a sample of $P$. multocida DNA isolated from saiga fallen during the epizootic in 2016, from the collection of "National Reference Center for Veterinary Medicine". Cultivation of the P. multocida strains was carried out on meat peptone agar (HiMedia, India). DNA was isolated using the QIAamp DNA Mini Kit manufactured by QIAGEN (USA) according to the manufacturer's instructions. DNA concentration was determined using a NanoDrop1000 spectrophotometer. We also used RNA samples isolated using the GeneJET Viral DNA and RNA Purification Kit (ThermoScientific) from patients diagnosed with SARS-Cov2 coronavirus infection.

PCR amplification. Amplification of the 16S rRNA gene fragment was performed with universal primers $8 f 5$ 'and $806 \mathrm{R}$ [20] in a total volume of $30 \mathrm{ul}$. The PCR mixture contained 2 ng of $P$. multocida DNA, $1 \mathrm{U}$ Taq DNA Polymerase (ThermoScientific), $0.2 \mathrm{mM}$ of each dNTP, 1xPCR KCl buffer, $2.5 \mathrm{mM} \mathrm{MgCl} 2,30$ 
pmol of each primer. Excess primer was used as a purification control. The PCR program: denaturation at $95^{\circ} \mathrm{C}$ for $5 \mathrm{~min}, 30$ cycles $\left(95^{\circ} \mathrm{C}\right.$ for $35 \mathrm{~s}, 55^{\circ} \mathrm{C}$ for $30 \mathrm{~s}$ and $72^{\circ} \mathrm{C}$ for $60 \mathrm{~s}$ ) and final elongation at $72^{\circ} \mathrm{C}$ for $5 \mathrm{~min}$. PCR was performed using a MasterCycler Gradient thermal cycler (Eppendorf).

Amplification of SARS-Cov 2 virus fragments was performed in a total volume of $25 \mu 1$ using a SuperScript III One-Step RT-PCR Platinum Taq Hi-Fi Set (Invitrogen), according to the manufacturer's instructions. Each reaction contained $10 \mathrm{pmol}$ of direct and reverse primers and $5 \mu \mathrm{l}$ of RNA. The PCR program: reverse transcription stage at $56^{\circ} \mathrm{C}$ for $30 \mathrm{~min}$; denaturation of $94^{\circ} \mathrm{C}$ for $3 \mathrm{~min} ; 35$ cycles $\left(94^{\circ} \mathrm{C}\right.$ for $15 \mathrm{~s}, 58^{\circ} \mathrm{C}$ for 30 $\mathrm{s}, 68^{\circ} \mathrm{C}$ for $2 \mathrm{~min}$ ) and final elongation at $68^{\circ} \mathrm{C}$ for $5 \mathrm{~min}$. PCR was performed using a MasterCycler Gradient thermal cycler (Eppendorf).

Enzymatic purification. Enzymatic purification of PCR products for sequencing was performed using Exonuclease I (ThermoScientific) and alkaline phosphatase (Shrimp Alkaline Phosphatase, ThermoScientific) [21].

Purification using magnetic particles coated with silica gel. Optimization of PCR purification of products using magnetic particles coated with silica gel. For this purpose, were prepared 4 variants of binding buffer systems containing different concentrations of PEG 8000 (polyethylene glycol) (AppliChem) and $\mathrm{NaCl}$ : PEG_1 (9.1\% PEG 6000 in $2 \mathrm{M} \mathrm{NaCl}$ ), PEG_2 (15\% PEG 8000 in $1.5 \mathrm{M} \mathrm{NaCl})$, PEG_3 (15\% PEG 8000 in $2 \mathrm{M} \mathrm{NaCl}), \mathrm{PEG}_{-} 4$ (20\% PEG 8000 in $\left.2.5 \mathrm{M} \mathrm{NaCl}\right)$. Silica gel particles have abrasive properties and, when rubbed against each other, form nanosized impurities. Therefore, before using magnetic silica gel, it must be washed with sorption buffer (10mM Tris-HCl, ph $8.01 \mathrm{mM}$ EDTA, $\mathrm{pH}$ 8.0) to remove fine impurities and optimize $\mathrm{pH}$. Magnetic silica gel (5\% molbiol.ru) was added immediately before use to a concentration of $0.1 \%$. As eluting solutions, $1 \mathrm{x}$ TE $\mathrm{pH}-9.2(10 \mathrm{mM}$ Tris- $1 \mathrm{mM}$ EDTA), deionized water, $10 \mathrm{mM}$ Tris $\mathrm{HCl} \mathrm{pH}-8,1 \times$ TE buffer $\mathrm{pH} 8.0$ were used.

The products of 20 PCR $16 \mathrm{~S}$ rRNA reactions of $P$. multocida were mixed and transferred $20 \mu$ into 25 tubes, 24 of which were used to verify purification using various concentrations of PEG and elution solutions, and 1 sample was a control. To 20 $\mu 1$ of the PCR product was added $30 \mu 1$ of PEG solution with magnetic silica gel, stirred on a shaker for 2 minutes at $1800 \mathrm{rpm}$. Incubated at room temperature for 10 minutes. After the stage of DNA binding with magnetic particles, the plate was placed on a magnetic tripod (00347252 Magnetic Stand-96, Invitrogen,) for 2 minutes, after the solution was clarified, the supernatant was removed. The magnets were washed twice with $100 \mu \mathrm{l}$ of $70 \%$ ethanol. The product was eluted in $20 \mu \mathrm{l}$ for 10 minutes at $60^{\circ} \mathrm{C}$, with shaking after 5 minutes of incubation on a shaker for 1 minute at $1600 \mathrm{rpm}$. Then the plate was placed on a magnetic tripod, the purified PCR product was taken and electrophoretic analysis was performed in $1.5 \%$ agarose. Concentration was measured on a Qubit ${ }^{\circledR} 2.0$ fluorimeter (Invitrogen) and with the dsDNA HS Assay Kit (Invitrogen).

Determination the dependence of ratio of PEG solutions on the size of adsorbing fragments. For this purpose, marker DNA was purified with fragments from 100 to $1000 \mathrm{bp}$ (100 bp step) with a variable ratio of the purified product to the $\mathrm{PEG} / \mathrm{NaCl}$ solution. The ratio of the volume of the PEG solution to the volume of the DNA marker ranged from 0.35 to 1.8 . A commercially available magnetic particle cleaning solution called AMPure XP (Beckman Coulter) was used as a control in an identical range.

\section{RESULTS}


Determination of the optimal PEG/NaCl solution.

To evaluate the efficiency of purification, a single protocol was used with the ratio of the PCR product and PEG solutions $8000 / \mathrm{NaCl}$ with silica-coated magnetic beads 1: 1.5. The highest adsorption efficiency of PCR products was observed in test tubes with 20\% PEG 8000 and $2.5 \mathrm{M} \mathrm{NaCl}$ (figure 1). In the phoregram with this solution, the highest luminescence intensity of the target PCR product was observed, but there was no low molecular weight nucleic acid (up to $100 \mathrm{bp}$ ). A quantitative assessment (table 1) confirms the highest efficiency of purification of PCR products with a solution of magnetic silica gel and 20\% PEG 8000 and $2.5 \mathrm{M} \mathrm{NaCl}$. The total DNA output in protocols with 9.1\% PEG 6000 in $2 \mathrm{M} \mathrm{NaCl}, 10 \%$ PEG 8000 in $1.5 \mathrm{M} \mathrm{NaCl}$ and $15 \%$ PEG 8000 in $2.0 \mathrm{M} \mathrm{NaCl}$ compared with $20 \%$ PEG 8000 in $2.5 \mathrm{M} \mathrm{NaCl}$ was on average lower by $97.2 \%, 76.7 \%$ and $29.2 \%$, respectively. Among the eluting solutions, $1 \mathrm{x}$ TE $\mathrm{pH}-8.0$, and $10 \mathrm{mM}$ Tris $\mathrm{HCl}, \mathrm{pH}-8$ was most effective.

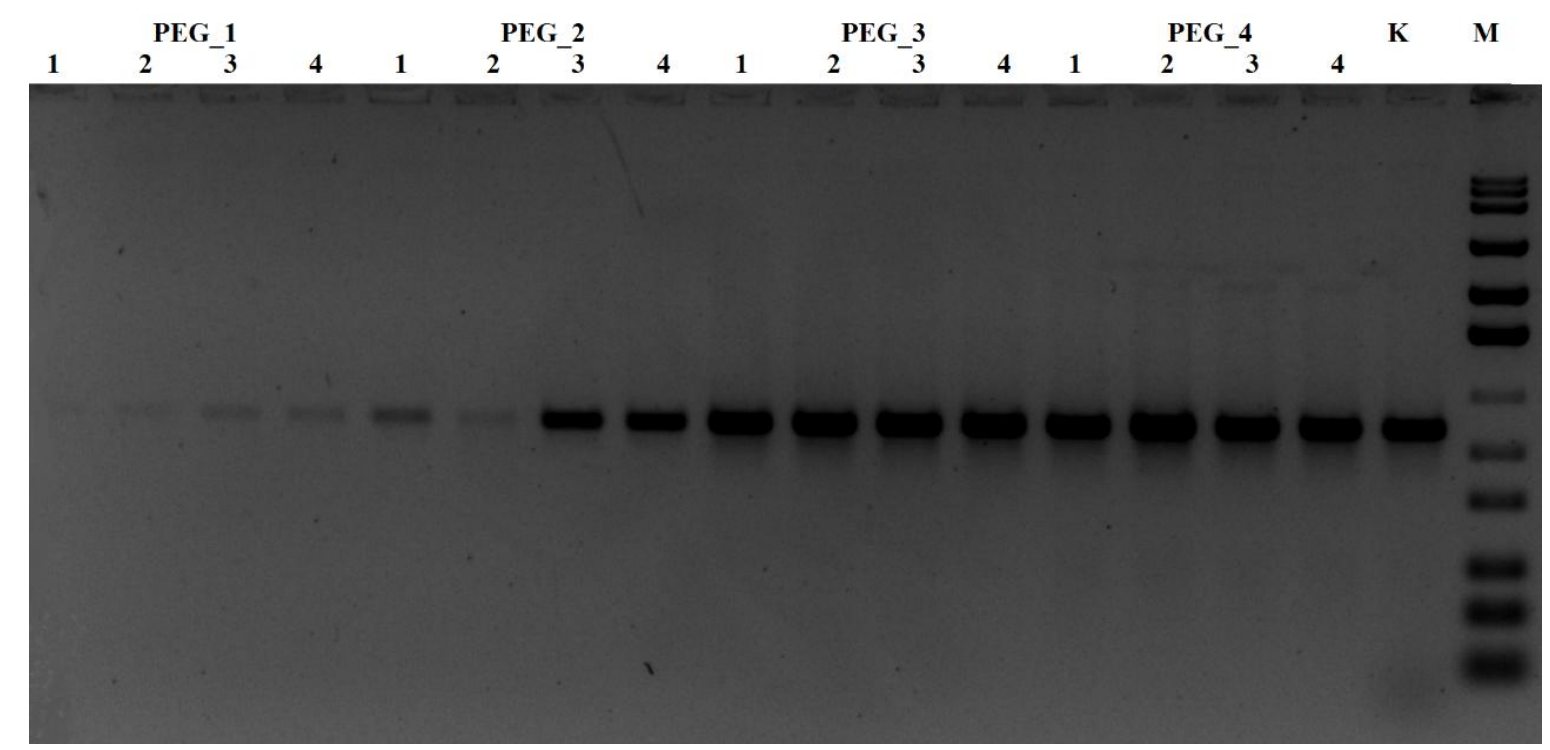

PEG_1 - 9.1\% PEG 6000/2 M NaCl; PEG_2 - 10\% PEG 8000/1.5 M NaCl; PEG_3 - 15\% PEG 8000/2.0 M NaCl; PEG_4 - 20\% PEG 8000/2.5 M NaCl.

Eluting solutions: 1 - 1xTE -pH 9.2, 2 -Dionized water, 3-10 mM TrisHCl pH 8.0, 4-1xTE -pH 8.0 M- \# SM1293, molecular weight marker from 100 to $10,000 \mathrm{bp}$

Fig.1. Purification quality of PCR products with different concentrations of $\mathrm{PEG} / \mathrm{NaCl}$

Table 1. Quantification of effectiveness the PCR products purification

\begin{tabular}{|c|c|c|c|c|}
\hline \multirow{2}{*}{$\begin{array}{l}\text { Purification } \\
\text { method }\end{array}$} & \multicolumn{4}{|c|}{ Concentration during elution with various solutions $\mathrm{ng} / \mu \mathrm{l}$} \\
\hline & $\begin{array}{ll}10 & \mathrm{mM} \\
\text { TrisHCl pH } \\
8.0\end{array}$ & $\begin{array}{c}1 \times \mathrm{TE}-\mathrm{pH} \\
8.0\end{array}$ & $\begin{array}{l}1 \mathrm{xTE} \quad-\mathrm{pH} \\
9.2\end{array}$ & Dionized water \\
\hline $\begin{array}{l}\text { 9.1\% PEG 6000/2 } \\
\mathrm{M} \mathrm{NaCl}\end{array}$ & 0.688 & 0.717 & 0.448 & 0.353 \\
\hline $\begin{array}{ll}10 \% & \text { PEG } \\
8000 / 1.5 \mathrm{M} \mathrm{NaCl}\end{array}$ & 5.53 & 7.03 & 4.53 & 1.71 \\
\hline $\begin{array}{ll}15 \% & \text { PEG } \\
8000 / 2.0 \mathrm{M} \mathrm{NaCl}\end{array}$ & 16.8 & 17.7 & 12.5 & 10.1 \\
\hline $\begin{array}{lr}20 \% & \text { PEG } \\
8000 / 2.5 \mathrm{M} \mathrm{NaCl}\end{array}$ & 20.3 & 20.5 & 20.0 & 19.8 \\
\hline
\end{tabular}


Estimation the ratio of PEG 8000 / $\mathrm{NaCl}$ with sizes of adsorbed fragments. Based on the results of optimizations, in further work we used PEG $800020 \%$ and 2.5 $\mathrm{M} \mathrm{NaCl}$ with $0.1 \%$ silica-coated magnetic beads. As an eluting solution, we used 1xTE, $\mathrm{pH}-8$. The optimized composition of PEG $8000 / \mathrm{NaCl}$ with magnetic silica gel in a ratio of 0.35 allows sorption of fragments from $500 \mathrm{bp}$, a ratio of 0.65 to 1.2 - from 200 $\mathrm{bp}$ (figure 2). The ratio of 1.8:1 adsorb fragments from $100 \mathrm{bp}$. Using a commercial AM Pure XP solution, a ratio of 0.35: 1 led to almost complete loss of a marker of all lengths, a ratio of $0.65: 1$ and $0.8: 1$ adsorb molecules from $300 \mathrm{bp}$, while a ratio of 1.2 : 1 and 1.8: 1 begins to adsorb DNA fragments with $200 \mathrm{bp}$.

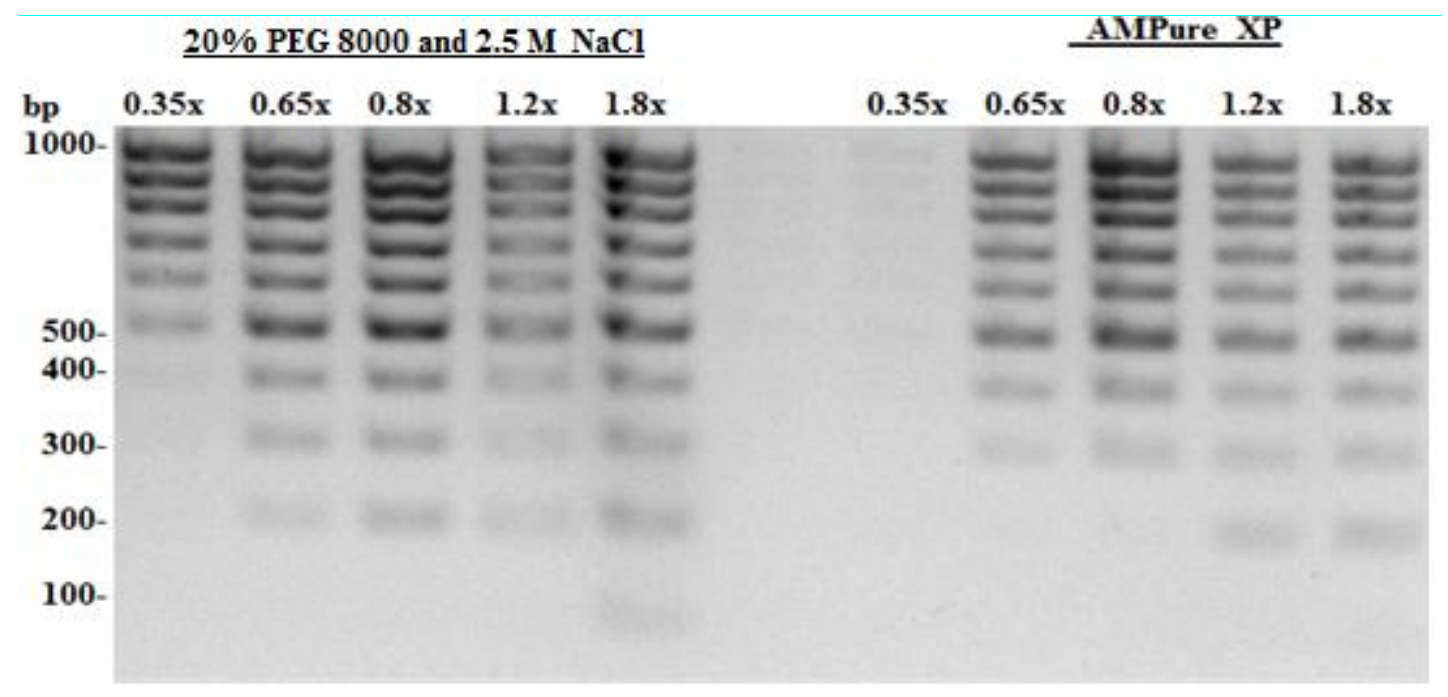

Fig. 2. Assessment the ratio of $\mathrm{PEG} 8000 / \mathrm{NaCl}$ with sizes of adsorbed fragments

Purification of PCR products for "Sanger" sequencing method. PCR products amplifying SARS-Cov2 fragments were used as the initial template. Amplification was performed on RNA samples isolated from nosopharyngeal swabs from patients with a positive diagnosis of coronavirus infection. High concentrations of non-targeted RNA generated non-specific low molecular weight fragments and smears (figure $3 \mathrm{~A}$ ), which led to a deterioration in the quality of sequencing PCR products purified by the enzymatic method (figure 4A). Using an optimized method with a ratio of $0.35: 1$ made it possible to significantly clear PCR products from low-molecular compounds (figure $3 \mathrm{~B}$ ), thereby improving the quality of sequencing (figure 4B). 


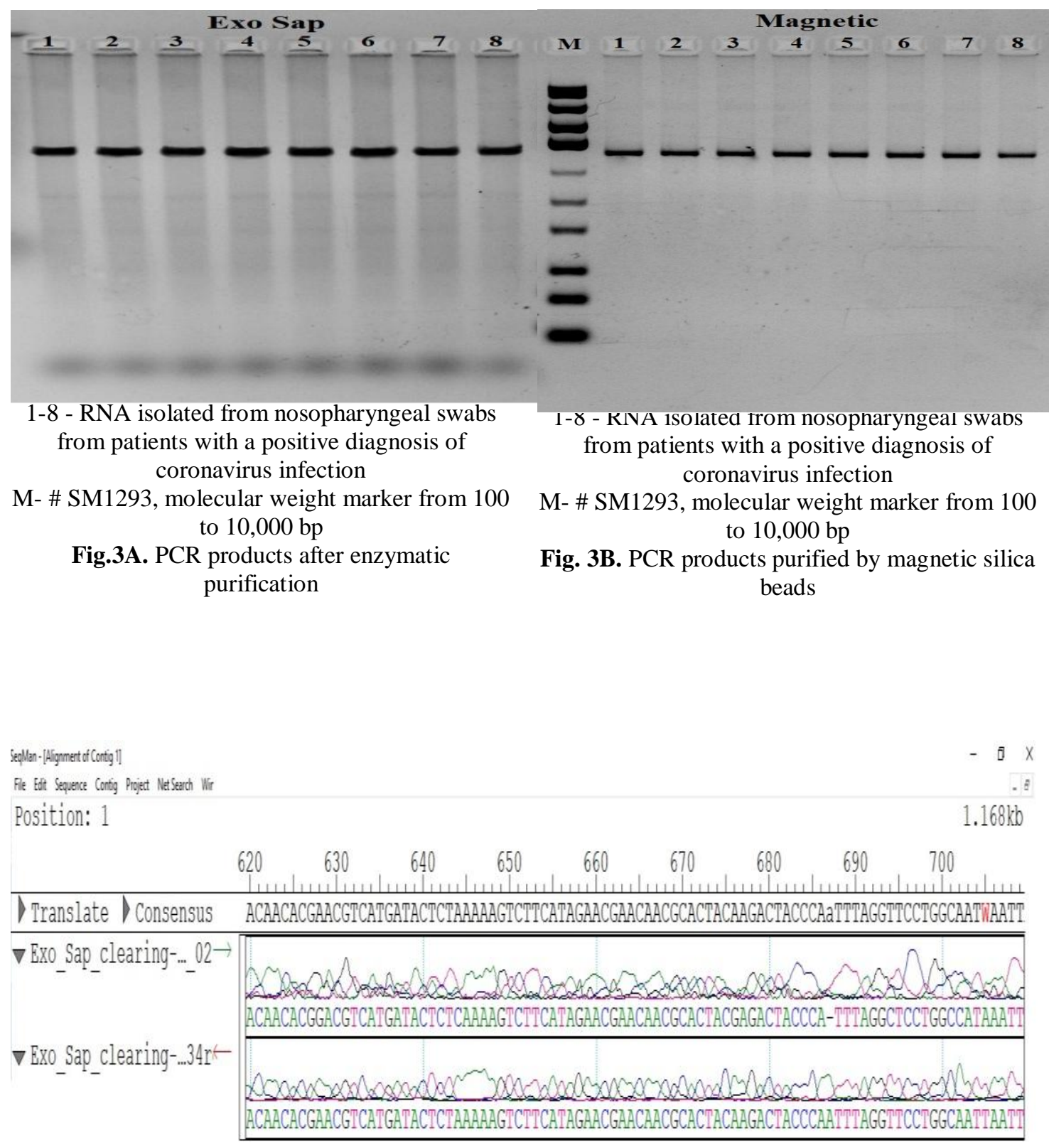

Fig. 4A. The result of sequencing of PCR products after enzymatic purification

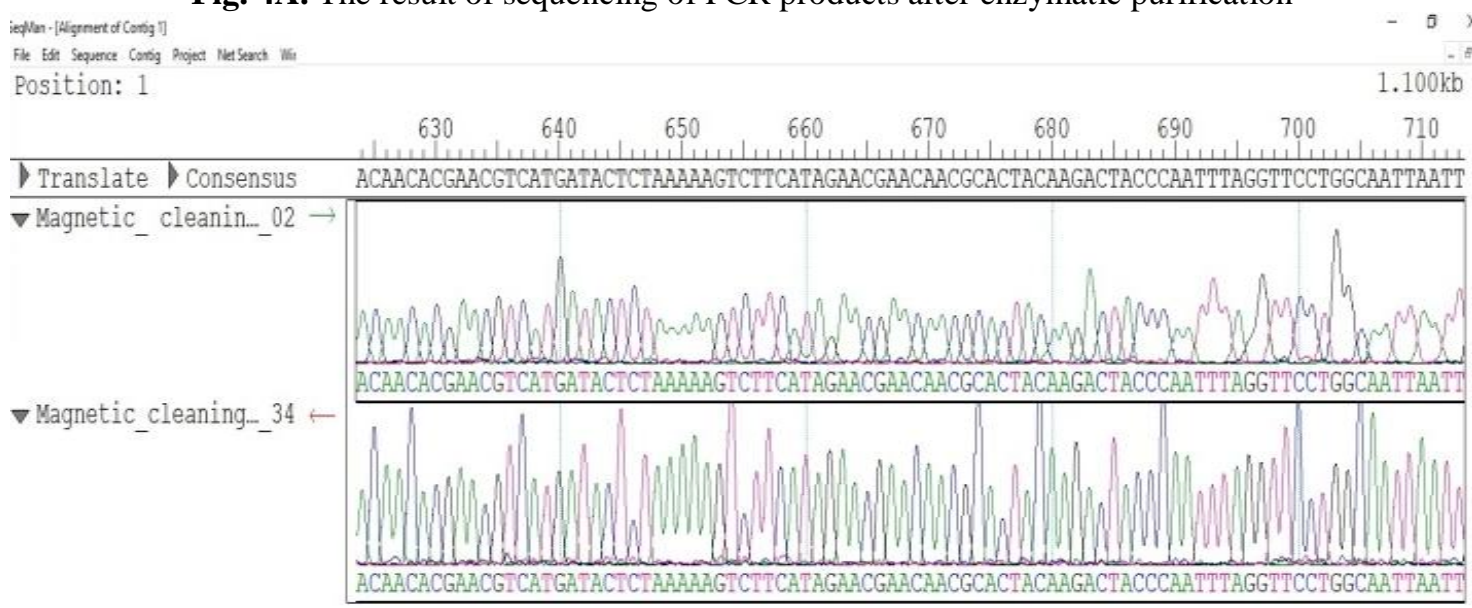

Fig. 4B. Kesult of sequencing of PCK products with magnetic silica beads

\section{DISCUSSION}

The use of magnetic particles for the isolation and purification of nucleic acids 
began in the 90s of the last century [22]. Currently, many sets of nucleic acid isolation and purification of PCR products have appeared on the market. Nevertheless, despite the simplicity of the methodologists, their cost is still high. In this article, we describe a protocol for the purification of PCR fragments using reagents standardly available in research laboratories. The developed protocol in its technical characteristics is not inferior to commercial analogues.

Magnetic silica gel is a particle of iron oxide coated with silica or polymer, which is why it has a magnetic moment and can move when exposed to a magnetic field. Creating a magnetic field at the edge of the test tube leads to the formation of a clot of magnetic silica gel at the place where the magnetic field is applied. This ability provides a number of advantages for methods based on magnetic particles in comparison with standard methods based on spin columns, silica gel, and nucleic acid precipitation. The absence of a centrifugation step allows to automate the process and reduce the risk of cross-contamination [23]. It allows one to isolate a product from large volumes with a low DNA concentration without increasing the process execution time $[24,25]$.

Size fractionation of DNA molecules is an important advantage that has found application in the preparation of samples for whole genome sequencing.

DNA size selection method is a two-step adsorption of DNA on magnetic particles. For this, at the first stage, high affinity binding of large DNA fragments with a length of more than $800 \mathrm{bp}$ occurs, which is achieved by adding a PEG / NaCl solution with paramagnetic particles in a ratio of $0.5: 1$ to the sample volume. For the second stage, the supernatant is transferred to a new tube into which PEG / $\mathrm{NaCl}$ with paramagnetic particles is added in a ratio of 0.7: 1. As a result, sorption of DNA fragments of more than $300 \mathrm{bp}$ occurs. After removal of unbound short DNA fragments and washing of magnetic particles, the sorbed fragments are eluted, which allows obtaining ready-made libraries of 300-800 bp in size. [26]. We used various concentrations of PEG8000 and $\mathrm{NaCl}$ with a constant concentration of magnetic silica beads. The use of the previously described concentrations of PEG8000 and $\mathrm{NaCl}[27$, 28] led to large losses of target fragments. Only an increase in the concentration of PEG8000 to $20 \%$ and NACl to $2.5 \mathrm{mM}$ led to a decrease in losses during the purification of PCR products. The optimized buffer, when used in a ratio of 1.5: 1 to the volume of DNA solutions, made it possible to purify PCR products from primers of dimers, salts, and other contaminating components of the reaction, retaining from 91.6 to $94.9 \%$ of DNA in solution.

Applying different ratios of volume of buffer systems with magnetic silica to the volume of the sample allowed to selectively adsorb DNA fragments by size. Thus, the ratio of 0.35: 1 made it possible to selectively adsorb fragments of more than $400 \mathrm{bp}$, which was used in the purification of PCR fragments containing low molecular weight smears. Purification using magnetic particles significantly improved Sanger sequencing results.

\section{CONCLUSIONS}

An optimized protocol allows purification of PCR products and is not inferior to commercial analogs in results.

\section{Acknowledgements}

This work was supported by the Ministry of Education and Science of the Republic of Kazakhstan (grant No. AP05133053 for 2018 - 2020 years). 


\section{REFERENCES}

1. Shan Zh, Li X, Gao Y, Wang X, Li Ch, Wu Q. Application of magnetic hydroxyapatite nanoparticles for solid phase extraction of plasmid DNA. Analytical Biochemistry, 2012, vol. 425, no.2, pp. 125-127. PMID: 22465330. doi: 10.1016/j.ab.2012.03.013

2. Ewers C., Lübke-Becker A., Bethe A., Kiebling S., Filter M., Wieler L.H. Virulence genotype of Pasteurella multocida strains isolated from different hosts with various disease status. Vet Microbiol, 2006, vol. 7, pp. 3-4.

3. Gautam R., Kumar A.A., Singh V.P., Singh V.P., Dutta T.K., Shivachandra SB.

Specific identification of Pasteurella multocida serogroup-A isolates by PCR assay. Res Vet Sci, 2004, vol. 3, pp.179-85.

4. Lundin S, Stranneheim H, Pettersson E, Klevebring D, Lundeberg J. Increased throughput by parallelization of library preparation for massive sequencing PLOS ONE, vol. 5, no.4. doi.org/10.1371/journal.pone.0010029

5. Mijatovic-Rustempasic S., Frace M., Bowen M. Cost-Effective Paramagnetic Bead Technique for Purification of Cycle Sequencing Products. Sequencing, 2012. doi:10.1155/2012/767959.

6. Sambrook J., Russell D. Molecular Cloning: A Laboratory Manual, Cold Sring

Harbor Laboratory Press, New York, NY, USA, 3rd edition, 2001.

7. Warren W., Doniger J. HPLC purification of polymerase chain reaction products for direct sequencing. BioTechniques, 1991, vol. 10, no. 2, pp. 216-220.

8. Salas-Solano O., Ruiz-Martinez M. C., Carrilho E., Kotler L., Karger B. L. A sample purification method for rugged and high-performance DNA sequencing by capillary electrophoresis using replaceable polymer solutions. B. Quantitative determination of the role of sample matrix components on sequencing analysis. Analytical Chemistry, vol. 70, no. 8, pp. 1528-1535.

9. Ruiz-Martinez M. C., Salas-Solano O., Carrilho E., Kotler L., Karger B. L., A sample purification method for rugged and high-performance DNA sequencing by capillary electrophoresis using replaceable polymer solutions. A. Development of the cleanup protocol. Analytical Chemistry, 1998, vol. 70, no. 8, pp. 1516-1527.

10. Pogue R. R., Cook M. E., Livingstone L. R., Hunt S. W. Preparation of template for tomated sequencing using QIAGEN resin. BioTechniques,1993, vol. 15, no. 3 , pp. $376-381$.

11. Elkin C. J., Kapur H., Smith T. Magnetic bead purification of Labeled DNA fragments for high-throughput capillary electrophoresis sequencing. BioTechniques, 2002, vol. 32, no. 6, pp. 1296-1300.

12. Fry G., Lachenmeier E., Mayrand E. A new approach to template purification

for sequencing applications using paramagnetic particles. BioTechniques, 1992, vol. 13, no. 1, pp. 124-131.

13. Z.M. Saiyed., Ramchand C.N. Extraction of Genomic DNA Using Magnetic Nanoparticles (Fe3O4) as a Solid-Phase Support. American Journal of Infectious Diseases, 2007, vol. 3, no 4, pp. 225-229.

14. Saiyed, Z.M., Bochiwal C., Gorasia H, Telang S.D., Ramchand C.N. Application of magnetic particles $(\mathrm{Fe} 3 \mathrm{O} 4)$ for isolation of genomic DNA from mammalian cells. Anal.Biochem, 2006, vol.356, pp.306-308.

15. Farias-Hesson E, Erikson J, Atkins A, Shen P, Davis RW, Scharfe C, Pourmand N. Semi-automated library preparation for high-throughput DNA sequencing platforms. J Biomed Biotechnol, doi: 10.1155/2010/617469. 
16. Quail M.A, Kozarewa I, Smith F, Scally A, Stephens P.J, Durbin R, Swerdlow

H, Turner D.J. A large genome center's improvements to the Illumina sequencing system. Nat Methods, 2008, vol. 5, pp.1005-1010.

17. Borgstrom E, Lundin S, Lundeberg J 2011. Large scale library generation for high throughput sequencing. doi: 10.1371/journal.pone.0019119.

18. Oberacker P, Steppe P, Bond D, Höhn S, Focken J, Meyer V, Schelle L,

Sugrue V, Jeunen G, Moser T, Hore S, Meyenn F, Hipp K, Hore T, Jurkowski T. BioOn-Magnetic-Beads (BOMB): Open Platform for High-Throughput Nucleic Acid Extraction and Manipulation. doi: 10.1371/journal.pbio.3000107.

19. Genome R. Cost-effective, High-Throughput DNA Sequencing Libraries for Multiplexed Target Capture Nadin Rohland. doi: 10.1101/gr.128124.111.

20. Joan E., Edwards Sh., Joong K., Alison H. Characterization of the dynamics of initial bacterial colonization of nonconserved forage in the bovine rumen. FEMS Microbiology Ecology, 2008, vol. 63, pp. 141-142. doi.org/10.1111/j.15746941.2007.00413.x

21. Werle E., Schneider C., Renner M., Völker M., Fiehn W. Convenient single step, one tube purification of PCR products for direct sequencing. Nucleic Acids Res, 1994, vol. 22, pp. 4354-4355.

22. Hawkins TL, O'connor-morin T, Roy A, Santillan C. DNA purification and isolation using a solid-phase. Nucleic Acids Res, 1994, vol. 22, pp. 4543-4544.

23. Berensmeier S. Magnetic particles for the separation and purification of nucleic acids. Appl Microbiol Biotechnol, 2006, vol. 3, no. 3, pp. 495-504. doi: 10.1007/s00253-006-0675-0

24. Pandoh P., Corbett R., McDonald H., Alcaide M., Kirk H., Trinh E., Haile S.,

MacLeod T., Smailus D., Bilobram S., Mungall A., Ma Yu, Moore R., Coope R., Zhao Yo, Jones S., Holt R, Karsan A, Morin R., Marra M. A High-Throughput Protocol for Isolating Cell-Free Circulating Tumor DNA From Peripheral Blood. Biotechniques, 2019, vol. 66, no.2, pp. 85-92. doi: 10.2144/btn-2018-0148.

25. Sorber L., Zwaenepoel K., Deschoolmeester V., Roeyen G., Lardon F., Rolfo Ch., Pauwels P.A Comparison of Cell-Free DNA Isolation Kits: Isolation and Quantification of Cell-Free DNA in Plasma. The Journal of Molecular Diagnostics, 2017, vol. 19, no. 1, pp. 162-168.

26.Lennon N., Lintner R., Nicol R. A scalable, fully automated process for construction of sequence-ready barcoded libraries for 454. Genome Biology, 2010, vol. 11, pp. 15.

27. Ming Zh., Xianqing Zh., Sen W., Chao Ch., Yali C. A simple method for purification of genomic DNA from whole blood using $\mathrm{Fe} 3 \mathrm{O} 4 / \mathrm{Au}$ composite particles as a carrier. Journal of Medical Colleges of PLA, 2009, vol. 24, pp. 239-243.

28. Rittich B., Spanov A., Horak D., Benes M.J., Klesnilova L., Petrova K., Rybnika A. Isolation of microbial DNA by newly designed magnetic particles. Biointerfaces, 2006, vol. 52, pp. 143-148. 


\section{ОПТИМИЗАЦИЯ МЕТОДА ОЧИСТКИ ПЦР МАГНИТНЫМ СИЛИКАГЕЛЕМ}

Бердимуратова К.Т., Амиргазин А.О., Куйбагаров М.А., Луцай В.Б., Муканов К.К, Шевцов А.Б.

Национальный центр биотехнологии

Коргальжинское шосее, 13/5, Нур-Султан, 010000, Казахстан

bianco-umka@mail.ru

\section{АБСТРАКТ}

Очистка нуклеиновых кислот по-прежнему является важным шагом в молекулярно-генетических исследования. Развитие технологий секвенирования всего генома ужесточила требования к чистоте используемых нуклеиновых кислот, а также потребовало проводить селекцию фрагментов ДНК по размерам. Буферные системы, содержащие растворы ПЭГ / $\mathrm{NaCl}$ и магнитные шарики, покрытые силикагелем, позволяют очищать нуклеиновые кислоты и избирательно сорбировать определенные размеры ДНК. В этой статье мы представляем простой протокол для очистки продуктов ПЦР с возможностью поглощения необходимых молекул ДНК. Было установлено, что использование оптимизированной буферной системы ПЭГ / NaCl с магнитным силикагелем в соотношении 1,5: 1 с продуктом ПЦР позволяет избавиться от фрагментов ДНК 100 и менее пар оснований (п.н.), а также от других загрязняющих веществ сохраняя более $90 \%$ ДНК в растворе. Соотношение 0,35: 1 обеспечивает высокоаффинную сорбцию молекул ДНК более 400 п.н. Практическое использование позволило улучить качество получаемых результатов секвенирования без увеличения стоимости исследований.

Ключвые слова: магнитные частицы, покрытые силикагелем, очистка, ДНК, ПЦР продукты.

\section{ПТР ӨНІМДЕРІН СИЛИКЕГЕЛМЕН ҚАПТАЛҒАН МАГНИТТІ БӨЛШЕКТЕРМЕН ТАЗАЛАУ ӘДІСІН ОНТАЙЛАНДЫРУ}

Бердімұратова К.Т., Амиргазин А.О., Куйбагаров М.А., Луцай В.Б., Мұқанов Қ.К, Шевцов А.Б.

Ұлттық биотехнология орталывы

Қорвалжын тас жоль, 13/5, Нұр-Сұлтан, 010000, Қазақстан

bianco-umka@mail.ru

\section{ТYЙІН}

Молекулалық - генетикалық зерттеулердегі маңызды мәселелердің бірі нуклеин қылшылдарын тазалау. Толық геномдық секвенирлеу технологиясының дамуы нуклеин қышқылдарының тазалығына деген талапты, сонымен қатар ДНҚ фрагментін өлшемі бойынша сұрыптау жүргізуді күшейтті. Құрамында ПЭГ/NaCl және магнитті түіршіктер бар буферлі жүйе нуклеин қышқылдарын тазартып, ДНҚ-ның белгілі 
өлшемдерін сіңіруге мүмкіндік береді. Бұл мақалада ПТР өнімдерін, қажетті ДНҚ молекулаларын сіңіру арқылы тазартудың қарапайым әдісін ұсынамыз. ПЭГ / $\mathrm{NaCl}$ мен магнитті силикагелдің оңтайландырылған буферлі жүйені, ПТР өнімімен 1,5:1 ара-қатынаста қолдану арқылы, ДНК фрагменттерінің 100 ж.н және одан да кем жұп негіздерінен, басқа да ластанушылардан құтылуға мүмкіндік туғызады. Сонымен қатар ДНҚ-ның 90\%-ы сақталады. 0,35:1 ара-қатынасты қолдану ДНҚ-ның 400 ж.н.-тен жоғары молекулаларды сіңіруді қамтамасыз етеді. Әдісті практикалық қолдану арқылы алынатын секвенирлеу нәтижелерін сапасын зерттеудің құнын жоғарлатпай жақсартуға үлесін тигізді .

Негізгі сөздер: силикагелмен қапталған магнитті бөлшектер, тазарту, ДНК, ПТР өнімдер. 